AJIE - Asian Journal of Innovation and Entrepreneurship

(e-ISSN: 2477-0574; p-ISSN: 2477-3824)

Vol. 01, No. 01, January 2016

\title{
THE EFFECT OF CORPORATE GOVERNANCE, TENURE AUDIT AND QUALITY OF EARNINGS TOWARDS AUDIT DELAY WITH AUDITOR'S SPECIALIZATION AS THE VARIABLE OF MODERATION
}

\author{
Anggi Prayuda Panggabean, Reni Yendrawati \\ Faculty Economics Islamic University of Indonesia \\ E-mail: reni.yendrawati@uii.ac.id, anggiprayuda@gmail.com
}

\begin{abstract}
This study was aimed to find out the effect of corporate governance, tenure audit, and quality of earning towards audit delay (audit report lag) with auditor's specialization as the variable of moderation (empirical studies on manufacturing companies listed in Indonesian Stock Exchange in 2011-2013). Corporate governance authorized with the managerial ownership, independent board, institutional ownership, tenure audit and quality of earning became independent variables. Audit delay (audit report lag) became the dependent variable. The total of samples tested by 67 companies was selected by purposive sampling method. The data used is secondary data with the media in the form of financial reports of manufacturing companies. This study analyzed the company's audited financial reports by employing an analysis technique using descriptive and statistical analysis. The finding of this study indicated that the tenure audit moderated by auditor's specialization provides audit delay which is shorter than the nonspecialist auditors, while managerial ownership, independent board, institutional ownership and quality of earning is not proven to be moderated by the auditor's specialization towards audit delay.
\end{abstract}

Keywords: Audit delay, corporate governance, tenure audit, quality of earning, and the auditor's specialization.

\begin{abstract}
ABSTRAK
Penelitian ini bertujuan untuk mengetahui pengaruh tata kelola perusahaan, pemeriksaan kepemilikan, dan kualitas produktif terhadap audit delay (audit laporan lag) dengan spesialisasi auditor sebagai variabel moderasi (studi empiris pada perusahaan manufaktur yang terdaftar di Bursa Efek Indonesia pada 2011- 2013). tata kelola perusahaan yang berwenang dengan kepemilikan manajerial, dewan komisaris independen, kepemilikan institusional, pemeriksaan kepemilikan dan kualitas produktif menjadi variabel independen. audit delay (audit laporan lag) menjadi variabel dependen. Total sampel diuji oleh 67 perusahaan terpilih dengan metode purposive sampling. Data yang digunakan adalah data sekunder dengan media berupa laporan keuangan perusahaan manufaktur. Penelitian ini menganalisis laporan keuangan perusahaan yang telah diaudit dengan menggunakan teknik analisis menggunakan analisis deskriptif dan statistik. Temuan penelitian ini menunjukkan bahwa audit masa dimoderatori oleh spesialisasi auditor memberikan audit delay yang lebih pendek dari auditor non-spesialis, sementara kepemilikan manajerial, dewan komisaris independen, kepemilikan institusional dan kualitas produktif tidak terbukti dimoderasi oleh spesialisasi auditor terhadap audit delay.
\end{abstract}

Kata kunci: Audit delay, tata kelola perusahaan, pemeriksaan kepemilikan, kualitas laba, dan spesialisasi auditor. 


\section{INTRODUCTION}

The development of economic level of Indonesia growing well and very rapidly is also followed by the development of investment in Indonesia. Because of the development of investment in Indonesia, it makes the development of the number of companies listed on the stock market. Capital markets provide an opportunity to those who have surplus funds to invest in companies listed on the stock market (Indriyani and Supriyati, 2012). Before potential investors invest, they need some information about the state of the company, so that the investors will not do any wrong decision in investing. Due to the adequate information, the investors can make a rank of several inputs into the decision model by using a way in which the investors can compare the risk from two or more companies and may conclude that the company has a higher or lower risk comparing to other companies. One way to know is to look at the data of financial report. The purpose of financial report in PSAK No. 1 is to provide information related to the financial position, performance and changes in financial position of a company that are useful for the large number of users in making economic decisions. Financial reports also show the accountability of management for the use of resources entrusted to it.

Registered companies in the capital market have an obligation to submit financial reports being audited to the public. Based on the latest Decree of the Chairman of Capital Market Supervisory Agency and Financial Institution No. KEP-431/BL/2012, the Indonesian public companies are required to regularly submit the financial audit report on time. In addition to presenting the information in the relevant financial reports, financial reporting should also be on time so that no party feels disadvantaged. Because of the delay in the financial reports, the information is not useful anymore. According to Haryani and Wiratmaja (2014), the implementation of further audit getting suitable with the standard requires longer time, thus it causes a long delay audit. In the audit that is not appropriate with the standard taking only a short time so that the information resulted is less assured. The delays in the publication of the financial reports in the audit will be very detrimental to investors because it may increase the asymmetry information in the market, insider trading, and some rumors raise that make the market uncertain and also give signals or bad signs for the health condition of the company making bad image to the company in the market capital. Audit Delay is the time difference between the end of the fiscal year to the published date of audit report (Indriyani and Supriyati, 2012). Reporting delay can cause a bad effect because it gives a bad signal (sign) is for the company, for example, in the Australian Capital Markets in 1974, the shares were prohibited to trade as the company were failed to submit the financial report based on its timely requirements for the exchange. Therefore, this study was conducted to examine the effect of managerial ownership, independent board, institutional ownership, audit tenure and quality of earning towards audit delay and to find out the effect of managerial ownership, independent board, institutional ownership, audit tenure and quality of earning towards audit delay with auditor's specialization as the variable of moderation that occurs in the manufacturing companies listed on the Indonesian Stock Exchange.

\section{LITERATURE REVIEW}

Effect of Managerial Ownership towards the Audit Delay (Audit Report Lag)

Managerial ownership includes the percentage of shares held by directors, 
managers and commissioners. The manager will always strive to enhance the corporate value by improving the performance of management. Based on the research conducted by Latrini and Swami (2013), in the presence of managerial ownership, the company's performance wiill be good, so that the audited financial reports will be issued on time.

\section{H1: Managerial Ownership positively influences on audit delay (audit report lag) Effect of Independent Commissioner}

\section{Board towards the Audit Delay (Audit} Report Lag)

Independent commissioner is a member of board of directors from outside the company and is not affiliated with the management, board of directors or other shareholder that may affect his independence. Swami and Latrini (2013), state that the independent board significantly influences to audit delay. Thus, independent board set up to oversee the behavior of management jobs cannot reduce the audit delay.

\section{H2: Independent Commissioner Boards} negatively influence to audit delay (audit report lag).

\section{Effect of Institutional Ownership towards Delay Audit (Audit Report Lag)}

Agency conflict that occurs between managers and shareholders can be minimized with institutional ownership. Institutional investors have the potential to influence directly management activities through their share ownership in the company. A good indication is when more company's stocks are owned by external shareholders rather than by internal shareholders (Ishak, Ahmad, and Rashid Sidek, 2010).

H3: Institutional ownership negatively influences to audit delay (audit report lag). Effect of the Audit Tenure towards Audit Delay (Audit Report Lag)

Based on the research resulted by Stone (2012), KAP audit tenure significantly influence tothe audit report lag (ARL). Based on the research conducted by Batu (2012), the variable of tenure audit is divided into two categories: first, the short tenure is when the auditor's tenure is during less than or equal to 9 years. Thus, short tenure aidit may cause audit delat (audit report lag). Habib and Bhuiyan (2011) suggest the longer tenure audit is, the more effect it may give to the presence of audit delay.

\section{H4: Audit tenure negative effect on audit delay (audit report lag).}

\section{Effect of Quality of Earning towards the} Audit Delay (Audit Report Lag)

According to Onofe, Ediae and Okunega (2013), they state that the total length of the time delay is measured by using the length of company's fiscal year-end date showing a significant effect on the quality of earning positively. The period of audit affects the accuracy of financial reporting (audit delay or timeliness). The value of reported earning is in accordance with the management objectives that are opportunistic. Opportunistic of earning surprise benchmarks will provide flexibility to the management to select accounting policies in maximizing the utility of management.

H5: The quality of earnings positive effect on audit delay (audit report lag). Effect of Managerial Ownership towards the Audit Delay (Audit Report Lag) with Auditor's Specialization as the Variable of Moderation

Auditor's specialization develops specific knowledge on certain industries, which then raises expectations that specialists' auditors are able to complete faster than the auditor who is not a specialist of industry by increasing the efficiency of audit (Habib and Bhuiyan, 2011). With the presence of managerial ownership in the company's stake ownership and the auditor's specialization can affect to the timely audited financial reports. With the above explanation, 
the specialization of industry's auditor can minimize audit delay in the company.

H6: Auditor's specialization influences to the relationship of managerial ownership towards audit delay (audit report lag).

Effect of Independent Commissioner Board towards the Audit Delay (Audit Report Lag) with Auditor's Specialization as the Variable of Moderation

Independent commissioners boards can create investors' trust to the company's performance. With the presence of specialization of auditors, it makes relevant financial reports. Also, it makes the financial reports may be presented on time, so it makes the information contained in the report are relevant for investors. In Rustriani and Sugiarti (2013)'s research, it states that the auditor specialization will minimize audit delay in the company.

H7: Auditor's Specialization influences to the relationship of independent board and audit delay (audit report lag).

Effect of Constitutional Ownership towards Audit Delay (Audit Report Lag) with Auditor's Specialization as the Variable of Moderation

Auditor's specialization is as a form of trust from the clients towards the quality of financial reports produced by the auditor to the client. With the specialization of auditors, it can publish financial reports on time. However, instead of its exact time and quality, financial reports are relevant to serve as a reference for investors to invest. Good auditor's specialization can make the audited financial report are not late in publishing, so that information could be used in decision making. With the institutional ownership, it can allow the auditor to conduct audits in the clients' companies.

H8: Auditor's specialization inflluences to the relationship of institutional ownership and the audit delay (audit report lag).
Effect of the Tenure Audit towards Audit Delay (Audit Report Lag) with Auditor's specialization as the Variable of Moderation

Tenure audit significantly influences to audit delay (audit report lag). Short tenure audit makes an audit report lag becomes longer so it makes the delay in the issuance of financial reports (Batu, 2012). The presence of a study conducted by Habib and Bhuiyan (2011) indicates that the auditor's industry specialization influences to the relationship of tenure audit and audit report lag. The effect of audit tenure on the audit report lag will be further strengthened when the audit of financial report is conducted by the auditor's industry specialization. The longer tenure audit makes the auditor have an understanding of the nature of his client's business more and more, creates efficiency of audit and makes audit report lag is getting shorter.

H9: Auditor's specialization influences to the relationship of tenure audit and audit delay (audit report lag).

Effect of Earnings' Quality towards the Audit Delay (Audit Report Lag) with Auditor's Specialization as the Variable of Moderation

According to Habib and Bhuiyan (2011), it states that the knowledge and competencies possessed by the industry specialist auditors will affect to the increase of auditors' understanding. This results in an audit report lag which is getting shorter. Audit process undertaken by the industry specialist auditors is getting more quickly resolved than the auditor who is not a specialist. It is because of the understanding which is owned by specialist auditors is more in-depth, thereby it reduces the duration of the completion of the audit.

H10: Auditor's Specialization influences to the relationships of the earnings quality and audit delay (audit report lag). 


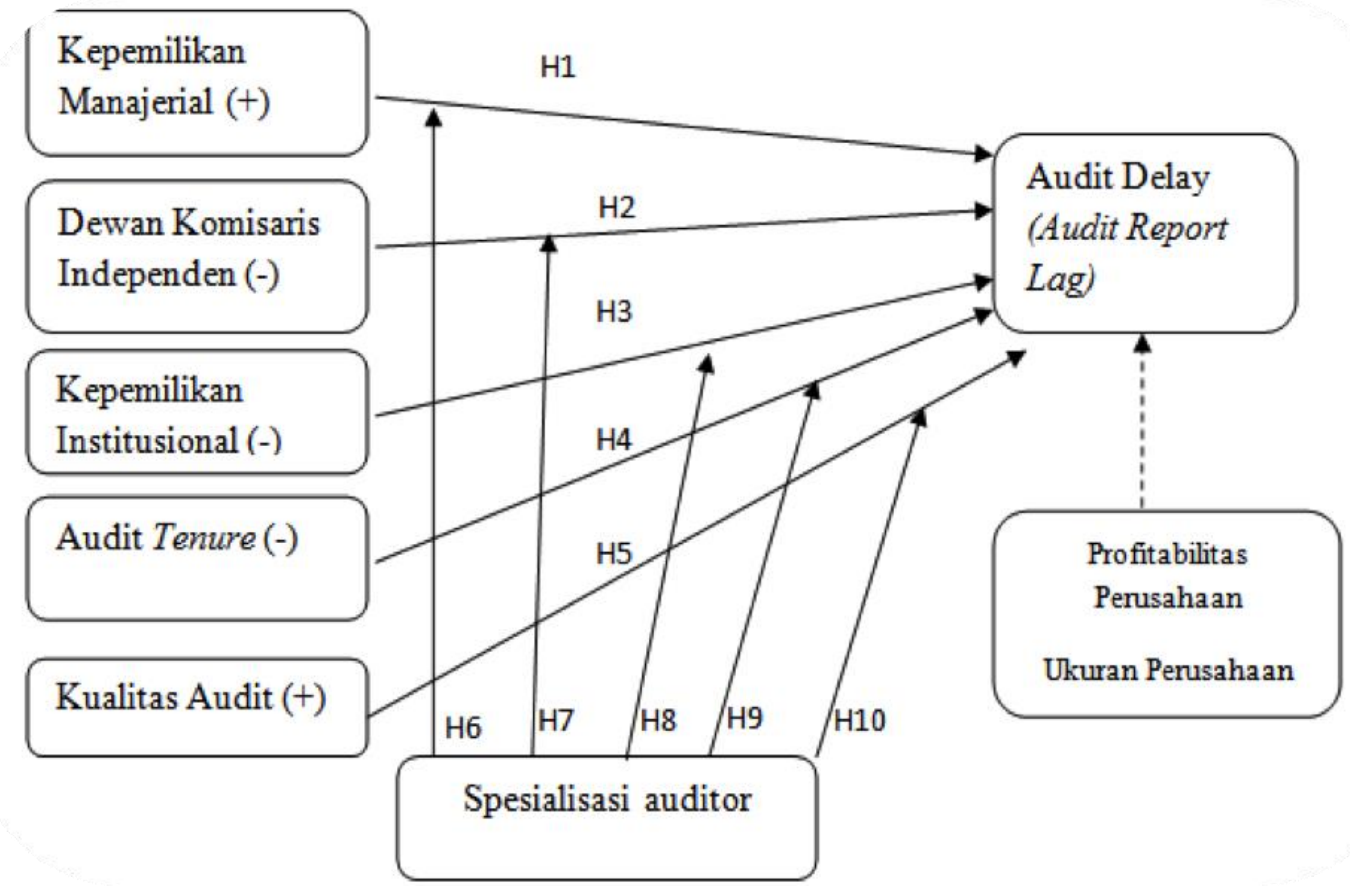

Figure 1:

Framework of the Hypothesis

\section{RESEARCH METHODS}

\section{Data Collection and Sampling}

The population in this study was the financial reports of companies listed in the Indonesian Stock Exchange. The sample in this study was manufacturing company's financial reports for the three-year observation period, namely in 2011, 2012, and 2013. The sampling method in this research was purposed sampling (purposive sampling). Manufacturing companies listed in Indonesia Stock Exchange in 2011-2013 are:

1. The company that publishes the company's annual reports (annual report), which ended on December 31, during the observation period of 2011,

2012, and 2013. The process of taking was done purposively. The data required were in the sample company's financial reports and the audit reports.

2. Companies that have data related to the Independent Commissioner, Institutional Ownership and Managerial Ownership.
3. Companies that have experienced positive sales during 2011 to 2013. Companies that use the rupiah currency in the financial reports.

\section{Definition and Measurement of the Research's Variables}

In this study, the audit report lag became the dependent variable as well as being the primary variable of the study. The definition of the audit report lag is the difference between the amount of the financial reporting date to the date of the audit report. It is because the regulation No. KEP431/BL/2012 just has been signed on 1 August 2012. Because the sample used was the audited financial reports for the year 2011, the audited financial reports was calculated from 3 months (90 days) and for the last audited financial reports of 2012 and 2013 used 4 months (120 days) after the date of the closing of the company's books.

\section{Ownership Manager}

Managerial stock ownership is a dummy variable coded 1 for companies that have a stake by the managerial and code 0 for companies that do not have ownership of 
shares by the company manager (Swami and Latrini, 2013).

\section{Independent Commissionner Board}

Independent board is a dummy variable coded 1 for companies that have independent board of more than $30 \%$ and code 0 for companies that have a board of directors is less than 30\% (Swami and Latrini, 2013).

\section{Institutional Ownership}

Institutional ownership is a dummy variable coded 1 for companies that have the institutional investors and code 0 for companies that do not have the institutional investors in the company (Swami and Latrini, 2013).

\section{Tenure Audit}

Tenure audit becomes independent variables by grouping firms employing tenure audit. The longer the company becomes a KAP client, the shorter audit delay will be. Companies that have been a KAP client for 3 years or more are given the value of 1 . The company becomes the client KAP less than 3 years old are given a value of 0 (Batu, 2012).

\section{Quality of earnings}

The quality of earnings as independent variables uses earning benchmarks between $\mu-\sigma$ and $\mu+\sigma$. This study assumes that poor earning quality is when (Dewi and Yuyetta, 2013): This study formulates the dependent variable of quality of earnings (KA) as follows: $\mathrm{KA}=1$ means good earning quality with the criteria of $\mu+\sigma<\mathrm{ROA}<\mu-\sigma$. And $\mathrm{KA}=0$ is defined as the poor audit quality with the criteria ROA $>\mu+\sigma$ or $\operatorname{ROA}<\mu-\sigma$.

\section{Variable of Moderation}

An auditor who is considered to have specialization is an auditor who has $15 \%$ of the total company in its industry group. Auditors' specialization in this study was measured by a dummy variable. The company audited by using auditor's specialization was coded 1 and the companies that did not use the auditor's specialization was coded 0 (Rustiarini and Sugiarti, 2013).

\section{Variable of Control}

In this study, the ability which was as a control variable is authorized as the return on assets (ROA), namely

Profitability $(R O A)=\frac{\text { Final Earnimg }}{\text { Asset Total }}$

Firm size was measured by using a logarithmic of sales total achieved by the company (Fauziah, 2010). By calculation:

\section{SIZE $=$ Ln Sales}

\section{Analysis Method}

The method used in this analysis is the analysis of quantitative data. With stages carried out to test the hypothesis employed multiple regression analysis.

\section{Multiple Regression Analysis}

In the model, it expresses the auditor's specialization influences to the relationship of the managerial ownership, independent board, institutional ownership, tenure audit and earning quality in the audit report lag that can affect negatively or positively, as well as the control variable profitability of the company and the size of the company. The testing of the model was by identifying value and the probability $\beta 1$ as follows:

$$
\begin{gathered}
\text { AUDLAY }= \\
\alpha+\beta 1(K M)+\beta 2(D K \text { ind })+\beta 3(K J)+\beta 4(A U T \text { Cnure })+\beta 5(Q E)+ \\
\beta 6 R O A+\beta 7 S I Z E+\beta B(K M) \times S P E C+\beta 9(D K i n d): B P E C+ \\
\beta 10(K I)+S P E C+\beta 11(A U T \text { Conure }) \times S P E C \\
+\beta 11(Q E)+S P E C+e
\end{gathered}
$$




\section{Description :}

AUDLAY = Audit Delay

KM $\quad=$ Managerial ownership

DKind =

Board of independent directors

KI = Institutional Ownership

AuTenure $\quad=$ Tenure Audit

QE $\quad=$ Quality of earnings

ROA = Profitabbility of companies

SIZE = Company Size

$\mathrm{KM} * \mathrm{SPEC}=$

Interaction of the Manager's Ownership and

Auditor's Specialization

DKind $*$ SPEC $=$

Interaction of Independent Commisioner

Board and Auditor's Specialization

$\mathrm{KI} * \mathrm{SPEC}=$

Interaction of Institutional Ownership and

Auditor's Specialization

AuTenure $*$ SPEC $=$

Interaction of Tenure Audit and Auditor's Specialization

$\mathrm{QE} *$ SPEC = Interaction of Quality of earnings and Auditor's Specialization

\section{Hypothesis Testing \\ F Statistical Test}

The testing criteria in this study used a significance level of $5 \%$ which is as follows (Ghazali, 2011): If $\mathrm{F}<0.05$ then $\mathrm{Ha}$ is accepted and Ho is rejected meaning there is no effect of independent variables towards the dependent variable simultaneously. If $\mathrm{F}>$ 0,05maka $\mathrm{Ha}$ is accepted and Ho is rejected meaning that there is the influence of independent variables on the dependent variable simultaneously.

\section{Test of Determination Coefficient (Test of Adjusted $\mathbf{R}^{2}$ )}

The purpose of this test is to show how big the influence of independent variables and how it explains the dependent variable in the equation made carefully. The assessment of the adjusted $\mathrm{R}^{2}$ with interval starting from the number 0 to $1(0 \leq \mathrm{R} 2 \leq 1)$.

\section{t Statistical Test}

With a significance level of $5 \%$, then the testing criteria are as follows (Ghazali, 2011): If the value of significance $t<0.05$, then Ho will be rejected, which means that a significant difference between all of the independent variables on the dependent variable. If the significance value of $t>0.05$, then Ho will be accepted, meaning there is a significant difference between all of the independent variables on the dependent variable.

\section{DATA ANALYSIS \\ Research Samples}

This study examined the companies listed in the Indonesia Stock Exchange in 2011 until 2013. The sampling technique used was purposive sampling. The technique of sampling collection can be seen in Table 1 below:

Table 1: The Basis of Sample Selection

\begin{tabular}{|l|c|}
\hline \multicolumn{1}{|c|}{ Description } & Total \\
\hline Companies listed on the Stock Exchange in 2011-2013 & $\mathbf{1 3 7}$ \\
\hline Companies using currencies other than Rupiah & $\mathbf{( 1 7 )}$ \\
\hline Never experienced negative sales & $\mathbf{( 4 7 )}$ \\
\hline No auditor's report & $\mathbf{( 6 )}$ \\
\hline The research sample & $\mathbf{6 7}$ \\
\hline Data observation of 3 x 67 & $\mathbf{2 0 1}$ \\
\hline
\end{tabular}

Source: Secondary Data Processed, 2015 
Multiple Linear Regression Analysis

The available data have been qualified to use multiple regression model.

Coefficient of Determination
The coefficient of determination $\left(\mathrm{R}^{2}\right)$ was used to measure how far the ability of the independent variables. The coefficient of determination is between zero and one. It can be seen in the following table:

Table 2: Test Results of Coefficient of Determination

Model Summary

\begin{tabular}{|c|c|c|c|c|c|}
\hline Model & $\mathrm{R}$ & $\mathrm{R}$ Square & $\begin{array}{c}\text { Adjusted R } \\
\text { Square }\end{array}$ & $\begin{array}{c}\text { Std. Error of the } \\
\text { Estimate }\end{array}$ & Durbin Watson \\
\hline 1 & 0.441 & 0.195 & 0.143 & 15.20544 & 1.839 \\
\hline
\end{tabular}

Source: Secondary Data Processed

Test $\mathbf{F}$

F statistical test basically shows whether all independent or independent variables are included in the model. It can be seen in the following table:

Table 3: Results of F Statistical Test

\begin{tabular}{|c|c|c|c|c|c|}
\hline Model & Sum of Squares & Df & Mean Square & F & Sig. \\
\hline Regression & 10506.877 & 12 & $\mathbf{8 7 5 . 5 7 3}$ & $\mathbf{3 . 7 8 7}$ & \\
\hline Residual & $\mathbf{4 3 4 6 6 . 6 2 5}$ & 188 & 231.205 & & \\
\hline Total & $\mathbf{5 3 9 7 3 . 5 0 2}$ & $\mathbf{2 0 0}$ & & & \\
\hline
\end{tabular}

Source: Secondary Data Processed

T test

$\mathrm{T}$ test was used to test how far the influence of the independent variables individually in explaining variations in the dependent variable (Ghozali, 2011).

Table 4: Results of T Statistical Test

\begin{tabular}{|c|c|c|c|c|c|}
\hline \multirow[b]{2}{*}{ Model } & \multicolumn{2}{|c|}{ Coeffisien } & \multicolumn{2}{|c|}{ T Test } & \multirow[b]{2}{*}{ Note: } \\
\hline & B & Beta & $\mathbf{T}$ & Sig & \\
\hline (Constant) & 122.212 & & 6.074 & .000 & \\
\hline KM & -0.586 & -0.018 & -0.223 & 0.824 & Not supported \\
\hline DKind & 0.876 & 0.018 & 0.264 & 0.792 & Not supported \\
\hline KI & 2.315 & 0.064 & 0.831 & 0.407 & Not supported \\
\hline AuTenure & -3.458 & -0.088 & -1.188 & 0.236 & Not supported \\
\hline$\overline{Q E}$ & 1.835 & 0.053 & 0.707 & 0.480 & Not supported \\
\hline ROA & -0.431 & -0.333 & -4.630 & 0.000 & Supported \\
\hline SIZE & -1.538 & -0.168 & -2.269 & 0.024 & Supported \\
\hline KM*SPEC & 1.807 & 0.030 & 0.334 & 0.738 & Not supported \\
\hline DKind*SPEC & 0.099 & 0.003 & 0.013 & 0.990 & Not supported \\
\hline KI*SPEC & -2.314 & -0.054 & -0.402 & 0.688 & Not supported \\
\hline
\end{tabular}




\begin{tabular}{|c|c|c|c|c|c|}
\hline AuTenure*SPEC & -1.799 & 0.169 & -2.539 & 0.028 & Supported \\
\hline QE*SPEC & -2.861 & -0.064 & -0.556 & 0.579 & Not supported \\
\hline
\end{tabular}

Source: Secondary Data Processed, 2015

\section{DISCUSSION OF RESULTS}

\section{Effect of Managerial Ownership towards the Audit Delay}

The results of multiple regression analysis were that partially managerial ownership variable has no significant effect on audit delay. This is shown by the $\mathrm{t}$ significant value of 0.824 or above the $5 \%$ of significance level. Thus, Ha1 stating that managerial ownership variables significantly influence to the partial audit delay is not proven.

The reason underlying this study is the absence of managerial ownership which does not affect audit delay. The management making financial reports which will be provided to interested parties still exists despite the presence or absence of ownership of the managerial in order to provide the accountability towards the implementation of the use of financial operations to the investor to invest in the sample company. Thus, the presence or absence of managerial ownership does not affect the performance of management in generating financial reports to the parties concerned as the accountability of the companies done during one accounting period. The results are consistent with the research conducted by Swami and Latrini (2013) which concluded that there was no significant effect of managerial ownership. Thus, $\mathbf{H}_{01}$ was accepted and $\mathbf{H}_{\mathbf{a} 1}$ was rejected.

\section{Effect of Independent Commissioner} Board towards the Audit Delay

The results of multiple regression analysis found that variable partial independent board does not have a significant effect on audit delay. This is shown by the $\mathrm{t}$ significant value of 0.792 or above the $5 \%$ significance level. Thus, Ha2 stating that the independent board variables significantly influence the partial audit delay is not proven.

The reason underlying this study is due to that the active role of the commissioners in practice very dependent on the environment created by the company concerned. This can be seen in the fact that many board members do not have the ability, and cannot demonstrate its independence (that in many cases the commissioners were also failed to represent the interests of other stakeholders other than the interests of the majority of shareholder). The results also found that the presence of independent directors did not significantly influence to the possibility of a delay audit. This is possible because the competence and integrity of the commissioner are weak, due to the appointment of independent directors only based on the appreciation, or because of family ties or close acquaintances. This is in accordance with the condition of Indonesian culture that is relatively free to give criticism on the other. The results are consistent with the research conducted by Nor, Shafie, and Houssin (2010) which concluded that there was no significant effect of independent board. Thus, $\mathbf{H}_{02}$ is accepted and $\mathbf{H}_{\mathbf{a} 2}$ is rejected.

\section{Effect of Institutional Ownership towards the Audit Delay}

The results of multiple regression analysis identified that variable partial institutional ownership has no significant effect on audit delay. This is shown to us by the significant value of $0,407 \mathrm{t}$ or above the $5 \%$ of significance level. Thus, Ha3 which states that institutional ownership variables 
significantly influence to the partial audit delay is not proven.

The reason underlying this study is due to the fact that not all institutional investors are sophisticated investors. Most investors just want to get the highest earnings in the company so that investors mostly invest in the short term. As the lack of the experience and the investment, it does not have effect on audit delay. Results of this study are not consistent with the studies conducted by Swami and Latrini (2013) which concluded that there is a significant influence of institutional ownership. From the regression results, it shows that $\mathbf{H}_{\mathbf{0 3}}$ was accepted and $\mathrm{H}_{\mathbf{a} 3}$ was rejected.

\section{Effect of Tenure Audit towards the Delay Audit}

The results of multiple regression analysis found that variable partial audit tenure has no significant effect on audit delay. This is shown to us by the $\mathrm{t}$ significant value of 0.236 or above the $5 \%$ of significance level. Thus $\mathbf{H}_{\mathbf{a} 4}$ which states that the audit tenure variables significantly influence the partial audit delay is not proven.

The reason underlying this study is due to the short tenure audit can generate long delay audit. Moreover, this study only look at KAP tenure audit on the sample company, yet it does not see the auditor's tenure audit towards the sample company. Tenure audit occuring is the auditor who audited the company changed although the sample comes from the same KAP, the process of understanding the characteristics of the operational businesses have understood that the absence of a long delay audit. The results of this study were not consistent with studies conducted by Batu (2012) which concluded there is significant influence audit tenure. From the regression results, it showed that $\mathbf{H}_{04}$ was accepted and $\mathbf{H}_{\mathbf{a} 4}$ was rejected. Effect of the Quality of Earnings towards the Audit Delay
The results of multiple regression analysis showed that the variable of quality of earnings partially does not have a significant effect towards the audit delay. This is shown by the $t$ significant value of 0.480 or above the $5 \%$ of significance level. Thus, $\mathbf{H}_{\mathbf{a} 5}$ stating that the variables of quality of earnings that significantly influence the partial delay audit is not proven.

The reason underlying this research is that the quality of earnings does not affect to the long delay audit. KAP conducting an audit of the financial reports checks the compliance towards the regulations running so that the good quality of earnings does not take a long time to produce audited financial reports. Therefore, the quality of earnings does not influence to the delay audit in the audited financial reporting to investor parties. The results of this study were not consistent with the studies conducted by Swami and Latrini (2013) which concluded that there is a significant influence on the quality of earnings towards audit delay. From the regression results, then $\mathbf{H}_{05}$ was accepted and $\mathrm{H}_{\mathbf{a} 5}$ was rejected.

Effect of Managerial Ownership towards the Delay Audit with the Auditor's Specialization as the Variable of Moderation

The results of multiple regression analysis found that the interaction of variables of moderation was that auditor's specialization predicted effect on managerial ownership relationship to the audit delay does not have a significant influence. This is shown by the $t$ significant value of 0.738 or above the $5 \%$ of significance level. Thus, $\mathbf{H}_{\mathbf{a b}}$ stating that managerial ownership variable moderated auditor specialization no significant effect on audit delay is not proven.

The reason underlying this study is the absence of managerial ownership; the management still makes financial reports will 
be provided to interested parties remain held for accountability in the use of finance for operations to the investor to invest in the sample company. Thus, when it is moderated by the auditor's specialization, it does not influence to the managerial ownership of audit delay. The auditor's specialization is different, so it cannot moderate the relationship between managerial ownership and audit delay. In this case, it can be concluded that there was no significant effect of managerial ownership on delay audit with the moderation of auditor's specialization. Therefore, $\mathbf{H}_{06}$ was accepted and $\mathbf{H}_{\mathbf{a 6}}$ was rejected.

Effect of Independent Commissioner Board towards the Delay Audit with Auditor's Specialization as the Variable of Moderation

The results of multiple regression analysis showed that the interaction of variables of moderation which is the auditor's specialization predicted to influence to the relationship to the commissioner board towards delay audit. It does not have a significant influence. This is shown by the $\mathrm{t}$ significant value of 0,990 or above the $5 \%$ of significance level. Thus, $\mathbf{H}_{\mathbf{a} 7}$ which states that the variable of independent board moderated by the auditor's specialization doesn not significantly influence to the delay audit is not proven.

The reason underlying this study is that the board members did not even carry out its oversight role which is fundamental to the board of directors. The Board of Commissioners is often considered to have no benefit. This can be seen in the fact that there are many board members which do not have the ability, and cannot demonstrate its independence (that in many cases the commissioners are also failed to represent the interests of other stakeholders other than the interests of the majority of shareholder). Thus, with the specialization of auditors who conduct audits on the company's financial reports, the sample cannot moderate the relationship between the independent board and audit delay. In this case, it can be concluded that there is no significant influence of independent board towards delay audit with moderation of auditor's specialization. Therefore, $\mathbf{H}_{07}$ was accepted and $\mathbf{H}_{\mathbf{a} 7}$ was rejected.

\section{Effect of Institutional Ownership towards}

Delay Audit with Auditor's Specialization as the Variable of Moderation

Results of multiple regression analysis that interaction moderating variables that specializes auditors predicted effect on institutional ownership relationship to the audit delay does not have a significant influence. This is showed to us by the $\mathrm{t}$ significant value of 0.688 or above the $5 \%$ of significance level. Thus, $\mathbf{H}_{\mathbf{a} 8}$ stating that institutional ownership variable moderated auditor's specialization significantly influences to delay audit is not proven.

The reason underlying this study is that institutional ownership just want a short-term investment that can benefit as highly as possible so it does not know about the state of the company, with the specialization of auditors who conduct audits in the financial reports can not give effect to the institutional ownership is thus not may moderate the relationship between managerial ownership and audit delay. In this case, it can be concluded that there was no significant effect of institutional ownership of the audit delay with moderation of auditor's specialization. Thus, $\mathbf{H}_{08}$ was accepted and $\mathbf{H}_{\mathbf{a} 8}$ was rejected.

\section{Effect of Tenure Audit towards Delay} Audit with the Auditor's Specialization as the Variable Moderation

The results of multiple regression analysis found that the interaction of moderating variables predicted to influence to the relationship between tenure audit and delay audit has a significant influence. It is 
showed by the $\mathrm{t}$ significant value of 0.028 or below the $5 \%$ of significance level. Thus, $\mathbf{H}_{\mathbf{a} 9}$ stating that the variable of managerial ownership moderated by auditor's specialization significantly influences to delay audit is not proven.

The reason underlying this study was because the tenure audit moderated by auditor's specialization influences to delay audit, as the auditor's specialization has an understanding of more comprehensive industrial characteritics. Thus, it has a negative role in the regression result so ut can moderate the relationship between tenure audit and delay audit. Although there is auditor's specialization, when the KAP tenure audits the sample company, it may start from the beginning as there is a difference between the auditor did the audit. As a result, it makes a longer audit process. In this case, auditor's specialization influences to tenure audit, so the findings of this study is in accordance to the research conducted by Swarni and Latrini (2013). Here, it can be concluded that there is a significant effect in tenure audit towards delay audit with the moderation of auditor's specialization. Therefore, $\mathbf{H}_{09}$ was rejected and $\mathbf{H}_{\mathbf{a} 9}$ was accepted.

\section{Effect of Earnings Quality Audit Delay towards the Specialization auditor as Variable Moderation}

The results of multiple regression analysis showed that the interaction of variables of moderation which is auditor's specialization predicted to influence to the relationship of quality of earnings and delay audit does not have significant influence showed by the $t$ significant value of 0,579 or above the $5 \%$ of significance level. Thus, $\mathbf{H}_{\mathbf{a} 10}$ which states that the variable of quality of earnings moderated by auditor's specialization significantly influence to audit delay is not proven.

The reason underlying this research is that the quality of earnings moderated by auditor's specialization does not affect to delay audit, with the specialization of auditors who audit the sample company's financial reports, so that financial report of audit produces good quality of earnings in a short time. In this case, the auditor's specialization does not affect to quality of earnings towards delay audit because of the determination of different auditor's specialization so it does not affect the quality of earnings. In this case, it can be concluded that there was no significant effect on the quality earnings and audit delay with moderation of auditor's specialization. Therefore, $\mathbf{H}_{010}$ was accepted and $\mathbf{H}_{\mathbf{a} 10}$ was rejected.

\section{Control Variables}

The variable the sample company's profitability authorized through the return on assets (ROA) has a significant effect on audit delay. It can be seen from the statistical probability ROA of 0.000 . These results are consistent with the results of research of Dewi and Yuyetta (2014). Thus, the profitability negatively influencing to the financial reporting period, because profit is a good news which tends to convey by the company more quickly.

The variable of size of the company has a negative and significant impact on audit delay, as seen from the SIZE variable coefficient is negative with probability value of 0,024 . These results are consistent with the study of the Batu (2012) which shows that the bigger the company, the faster the delivery of the company's financial reports, so that the period of completion of the audit is getting shorter.

\section{CONCLUSION AND SUGGESTION}

\section{Conclusion}

Based on the results of data analysis and hypothesis testing, some conclusions can be drawn as follows: Managerial Ownership, Board of Commissioners, institutional ownership, tenure and earnings quality audit 
have no significant effect on audit delay. The auditor's specialization has no significant effect on the relationship of managerial ownership and the audit delay. Thus, auditor's specialization as a variable of moderation does not affect the relationship of company's managerial ownership, board of independen tcommissioners, institutional ownership and quality of earnings towards delay audit. Auditor's specialization has a significant effect on the relationship of tenure audit to the delay audit. It is clear that the longer the tenure audit supported by industrial auditor's specialization, the shorter the delay audit will be. Thus, the auditor's specialization as a variable of moderation does not affect the result of good quality of companies' earning towards the delay audit.

\section{Research Limitations}

The determination of auditor's specialization in this study did not pay attention to the type of manufacturing company located in Indonesia. This can lead to the determination of industry's specialization becomes irrelevant between the types of manufacturing companies with each other. This study uses a percentage of sales total of the clients at a company and is only taken the positive ones for measuring the SIZE. Thus, it does not pay attention to the companies with the total of negative sales, so it does not measure the effect on delay audit.

\section{SUGGESTION}

The researchers realized that this research is still far from perfect. Therefore, the researchers gave suggestions for further research as follows: for further research, it is suggested to increase the number of research samples, so that the research results become more representative in reflecting the condition of the manufacturing company. Next, further research is suggested to take into account in the classification of a manufacturing company determining the auditor's specialization.
Then, further research can add variables that may affect the audit delay in the manufacturing sector, for example the age of the bank, going concern opinion and external parts that affect delay audit. Finally, future studies could replace the sample companies studied, for example, a service company

December 22, 2015

TRANSLATOR STATEMENT

The information appearing herein has been translated

by a Center for International Language and Cultural Studies of

Islamic University of Indonesia

CILACS UII JI. DEMANGAN BARU NO 24

YOGYAKARTA, INDONESIA.

Phone/Fax: 0274540255

\section{REFERENCES}

Batu, Lumban. "The Impacts of Auditor Specialization, Audit Tenure, and IFRS implementation on audit report lag: Indonesian Case”. Mini Economica edisi 40. 2012.

Dewi, S. G. P., dan Yuyetta, E. N. A. "Pengaruh Kualitas laba dan Audit Tenure Terhadap Audit Report Lag (ARL) dengan Spesialisasi auditor sebagai Variabel Moderasi”. Diponegoro Journal of Accounting. Vol. 3 No.2, hal. 1 - 11. 2014. Fauziah. "Faktor-Faktor yang Mempengaruhi Audit Delay pada Perusahaan Manufaktur yang Terdaftar Dalam Bursa Efek Indonesia". Skripsi Fakultas Ekonomi. Universitas Islam Indonesia. Sleman. 2010.

Ghozali, I. "Aplikasi Analisis Multivariate dengan Program IBM SPSS 19'.Semarang: Badan PenerbitUniverisitas Diponegoro. 2011.

Haryani. Jumratul dan Wiratmaja. "Pengaruh Ukuran Perusahaan, Komite Audit, Penerapan International Financial Reporting Standards Dan Kepemilikan Publik pada Audit Delay". E-Jurnal Akuntansi Universitas Udayana, 6.1, hal. 63-78. 2014.

Habib, Ahsan. and Md. Borhan Uddin Bhuiyan. "Audit Firm Industri 
Specialization and The Audit Report Lag.

Journal of Internatioanl Accounting. Auditing and Taxation”. Vol. 20, pp. 3344. 2011.

Institut Akuntan Publik Indonesia. "Standar Profesionalisme Akuntan Publik", Jakarta: Salemba Empat. 2013.

Indriyani., dan Supriyati. "Faktor-faktor yang mempengaruhi audit report lag perusahaan manufaktur Indonesia dan Malaysia". The Indonesian Accounting Review. 2012.

Ishak, I., Ahmad, S., M., Sidek., dan Rashid, A. A. "The Effect of Company Ownership on The Timeliness of Financial Reporting: Empirical Evidence from Malaysia". Unitar E Journal, Vol. 6 No. 2, June 2010.

Nor, M. N. M., Shafie, R., and Hussin, W. N. W. "Corporate Governance and Audit Report Lag in Malaysia. Asian Academy of Management Journal of Accouting and Financ"e, Vol. 6, No. 2, 57-84. 2010.

Onofe, O. A., Ediae, O. O., and Okunega, E. C. "Audit Delay and Audit Quality: Nigerian Experience". Research Journal of Social Science and Management. 2013.

Rustiarini., dan Sugiarti. (2013). Pengaruh Karakteristik Auditor, Opini Audit, Audit Tenure, dan Pergantian Auditor pada Audit Delay.Jurnal Ilmiah Akuntansi dan Humanika (Jinah), Juni 2013.

Suwardjono. (2011). Teori Akuntansi: Perekayasaan Pelaporan Keuangan. Edisi Ketiga, Yogyakarta: BPFE Cet. kelima.

Swami., dan Latrini. (2013). Pengaruh Karakteristik Corporate Governance Terhadap Audit Report Lag. E-Jurnal Akuntansi Universitas Udayana 4.3, hal. 530 - 549. 